\title{
Entorhinal Cortex Lesion in Adult Rats Induces the Expression of the Neuronal Chondroitin Sulfate Proteoglycan Neurocan in Reactive Astrocytes
}

\author{
Carola A. Haas, ${ }^{1}$ Uwe Rauch, ${ }^{2}$ Niklas Thon, ${ }^{1}$ Tobias Merten, ${ }^{1}$ and Thomas Deller ${ }^{1}$ \\ 1/nstitute of Anatomy, University of Freiburg, D-79001 Freiburg, Germany, and 2Department of Experimental Pathology, \\ Lund University Hospital, S-22185 Lund, Sweden
}

The chondroitin sulfate proteoglycan neurocan is a major component of brain extracellular matrix during development. Neurocan is primarily synthesized by neurons and has the ability to interact with cell adhesion molecules involved in the regulation of cell migration and axonal growth. Within the first weeks postnatally, neurocan expression is strongly downregulated. To test whether neurocan is reexpressed in areas of axonal growth (sprouting) after brain injury, the time course of neurocan expression was analyzed in the denervated fascia dentata of the rat after entorhinal cortex lesion (12 hr; 1, 2, 4, and $10 \mathrm{~d}$; 2 and 4 weeks; and 6 months after lesion). In the denervated zone, immunohistochemistry revealed neurocan-positive astrocytes by $2 \mathrm{~d}$ after lesion and a diffuse labeling of the extracellular matrix at all later time points. Electron microscopy confirmed the deposition of neurocan in the extracellular matrix compart- ment. In situ hybridization demonstrated a strong upregulation of neurocan mRNA within the denervated outer molecular layer 1 and $4 \mathrm{~d}$ after lesion. The combination of in situ hybridization with immunohistochemistry for glial fibrillary acidic protein demonstrated that the neurocan mRNA-expressing cells are astrocytes. These data demonstrate that neurocan is reexpressed in the injured brain. In contrast to the situation during development, astrocytes, but not neurons, express neurocan and enrich the extracellular matrix with this molecule. Similar to the situation during development, neurocan is expressed in an area of active axon growth, and it is suggested that neurocan acts to maintain the boundaries of the denervated fascia dentata after entorhinal cortex lesion.

Key words: extracellular matrix; sprouting; axon growth; plasticity; hippocampus; fascia dentata
Chondroitin sulfate proteoglycans (CSPGs) are major components of brain extracellular matrix (ECM) during development. They interact with cell adhesion molecules and are believed to regulate cell migration, axonal growth, and axonal pathfinding (Pearlman and Sheppard, 1996; Margolis and Margolis, 1997; Rauch, 1997; Yamada et al., 1997). After brain injury, CSPGs are upregulated in the glial scar surrounding the lesion site, and the failure of axons to regenerate in the CNS has been attributed, at least in part, to the presence of CSPGs in scar tissue (Höke and Silver, 1996; Davies et al., 1997, 1999; Stichel and Müller, 1998). In recent years, several CSPGs have been isolated from brain (Margolis and Margolis, 1997; Rauch, 1997). These molecules are differentially regulated during development (Milev et al., 1998), and it has been of considerable interest to characterize their specific functions.

A tightly developmentally regulated CSPG (Milev et al., 1998) that has received considerable attention is the brain-specific CSPG neurocan (Rauch et al., 1991). During embryonic development, neurocan is primarily expressed by neurons in the preplate, marginal zone, and subplate of the cortex before astrocytes

\footnotetext{
Received April 26, 1999; revised Sept. 3, 1999; accepted Sept. 3, 1999.

This work was supported by the Deutsche Forschungsgemeinschaft (Sonderforschungsbereich 505). We thank Anikò Schneider, Stefanie Studer, Susanne Huber, Regina Hertweck, and Marianne Winter for excellent technical assistance, Dr. Michael Frotscher for his continuous support and helpful comments on this manuscript, Dr. Reinhard Fässler for initiating this cooperation, Dr. Alisa Woods for constructive criticism of this manuscript, and Drs. Richard U. Margolis and Renée $\mathrm{K}$. Margolis for their generous gift of the neurocan antiserum NC-1.

Drs. Haas and Rauch contributed equally to this work.

Correspondence should be addressed to Dr. Thomas Deller, Anatomisches Institut I, Postfach 111, 79001 Freiburg, Germany. E-mail: dellerth@uni-freiburg.de Copyright (C) 1999 Society for Neuroscience 0270-6474/99/199953-11\$05.00/0
}

become evident (Oohira et al., 1994; Engel et al., 1996; MeyerPuttlitz et al., 1996). It is strongly downregulated during the first weeks postnatally (Rauch et al., 1991; Oohira et al., 1994). In vitro assays have shown that it has the ability to interact with several cell adhesion molecules and other molecules of the ECM involved in the regulation of cell migration and axonal growth. In particular, neurocan interacts with $\mathrm{N}-\mathrm{CAM}$ and L1/Ng-CAM, interferes with their homophilic interactions, and may thus disrupt axonal fasciculation (Friedlander et al., 1994; Grumet et al., 1994; Milev et al., 1996; Retzler et al., 1996). It also binds with high affinity to tenascin-C and may modify some of its functions on axons (Grumet et al., 1994; Rauch et al., 1997). Although these in vitro data and certain expression patterns in vivo (Watanabe et al., 1995; Tuttle et al., 1998) point to an inhibitory role of neurocan during axonal growth, in vivo studies demonstrate also that neurocan is expressed in regions of active fiber growth during development (Miller et al., 1995; Engel et al., 1996; MeyerPuttlitz et al., 1996; Pearlman and Sheppard, 1996; Fukuda et al., 1997). In either case, these studies suggest that neurocan delineates boundaries of axonal growth and that it may be important for neuronal pattern formation (Miller et al., 1995; Pearlman and Sheppard, 1996).

Local axonal growth (collateral sprouting) also occurs in denervated regions of the adult brain after injury (Raisman, 1969; Cotman et al., 1981). In these denervated regions, growthassociated molecules and cell adhesion molecules that regulate axonal growth during development are reactivated and participate in the regulation of the sprouting process. To test whether neurocan is similarly reexpressed in areas of sprouting, we analyzed the expression of neurocan using unilateral entorhinal cor- 
tex lesions (ECL), a well established model system for the analysis of collateral sprouting in the rat (Deller and Frotscher, 1997; Frotscher et al., 1997).

\section{MATERIALS AND METHODS}

Animals. Seventy-one adult male Sprague Dawley rats (250-350 gm; Charles River Wiga, Sulzfeld, Germany) housed under standard laboratory conditions were used in this study. For light microscopic immunohistochemistry, control rats $(n=3)$, and EC-lesioned rats surviving for $12 \mathrm{hr}(n=2), 1 \mathrm{~d}(n=2), 2 \mathrm{~d}(n=6), 4 \mathrm{~d}(n=6), 10 \mathrm{~d}(n=6), 14 \mathrm{~d}$ $(n=6), 4$ weeks $(n=6)$, and 6 months $(n=4)$ after lesion were used. For electron microscopy, EC-lesioned rats were allowed to survive for $14 \mathrm{~d}(n=2)$. For in situ hybridization, control rats $(n=4)$, shamoperated rats $1 \mathrm{~d}(n=2)$, and $4 \mathrm{~d}(n=2)$ after lesion and EC-lesioned rats surviving for $1 \mathrm{~d}(n=8), 4 \mathrm{~d}(n=8)$, and $6 \mathrm{~d}(n=4)$ after lesion were used.

Surgical procedures. All surgical procedures were performed under deep nembutal anesthesia (50 $\mathrm{mg} / \mathrm{kg}$ body weight), in agreement with the German law on the use of laboratory animals. In most cases, a standard electrocoagulator was used to make a unilateral cut in the frontal and sagittal plane between the entorhinal area and the hippocampus, which resulted in the complete destruction of the ipsilateral entorhinal afferents to the fascia dentata. In some animals that were used for in situ hybridization ( $n=4,1 \mathrm{~d}$ postlesion survival time; $n=4,4 \mathrm{~d}$ postlesion survival time), a glass knife was used to make the cut through the perforant pathway. The following coordinates measured from the interaural line were used: frontal cut, anteroposterior (AP), +1; lateral (L), 3-7; ventral (V), down to the base of the skull; sagittal cut, AP, +1 to $+4 ; \mathrm{L}, 6.7 ; \mathrm{V}$, down to the base of the skull (Deller et al., 1995). Completeness of ECL was verified macroscopically when the brains were sectioned on a vibratome and histochemically using the acetylcholinesterase (AChE) procedure described below (dense AChE staining in the outer molecular layer) (Lynch et al., 1972; Nadler et al., 1977; Naumann et al., 1997). The sham-operated animals were treated in the same way as the animals that received a complete unilateral ECL. However, the lesioning knife was lowered only into the cortex underlying the drill hole in the skull. An electrolytic lesion of this cortical region was performed and the knife was withdrawn.

Antibodies against neurocan. Two polyclonal rabbit antisera (NC-1 and $\mathrm{NC}-2$ ) were used for immunohistochemistry against neurocan. Antiserum NC-1, which was generously provided by Drs. R. U. Margolis and R. K. Margolis (New York University, New York, NY), and a second antiserum $\mathrm{NC}-2$ were prepared against native neurocan isolated from brain of 7-d-old rats by immunaffinity chromatography (1D1proteoglycan in Rauch et al., 1991). For NC-2, booster injections were performed with recombinant rat neurocan produced by mammalian cells and purified by immunaffinity chromatography (Retzler et al., 1996).

Western blot against neurocan. Protein samples were derived from brain and liver of 3-week-old mice, homogenized in 5 vol of cold $20 \mathrm{~mm}$ Tris/HCl, pH 8, $150 \mathrm{~mm} \mathrm{NaCl}$ [Tris-buffered saline (TBS)], containing protease inhibitors $(5 \mathrm{~mm}$ EDTA, $5 \mathrm{~mm}$ benzamidinium $\mathrm{Cl}, 5 \mathrm{~mm}$ $N$-ethylmaleimide, and freshly added $1 \mathrm{~mm}$ phenylmethylsulfonyl fluoride) with a dounce homogenizer. Chondroitinase digestions of the supernatant after a centrifugation at $15,000 \times g$ were performed in TBS with the indicated protease inhibitors and additional $100 \mathrm{~mm}$ Tris/ $\mathrm{HCl}$, $\mathrm{pH} 8.3$, and $30 \mathrm{~mm}$ sodium acetate, with $15 \mathrm{mU}$ chondroitin-ABC-lyase per sample. After a second homogenization with $5 \mathrm{vol}$ of the same buffer and centrifugation, the residual pellet was extracted with 5 vol of PBS containing protease inhibitors and $2 \%$ Triton X-100. The extract $(50 \mu \mathrm{l})$ was precipitated with $1 \mathrm{ml}$ of aceton, and the precipitate was dissolved in SDS sample buffer. All samples were run on $6 \%$ SDS-polyacrylamide gels under nonreducing conditions. SDS-PAGE and Coomassie blue staining or blotting of the samples on polyvinylidene difluoride membranes (Amersham Pharmacia Biotech, Freiburg, Germany) were performed according to standard procedures (Rauch et al., 1991). Immunoreactive protein bands were developed with the enhanced chemiluminescence system (Amersham Pharmacia Biotech).

Immunohistochemistry for neurocan. Rats were deeply anesthetized with an overdose of nembutal and were transcardially perfused with a fixative containing $4 \%$ paraformaldehyde, $0.1 \%$ glutaraldehyde, and $15 \%$ picric acid in $0.1 \mathrm{M}$ phosphate buffer (PB), $\mathrm{pH}$ 7.4. Brains were removed and post-fixed for $24 \mathrm{hr}$ in $4 \%$ paraformaldehyde in $0.1 \mathrm{M} \mathrm{PB}$. Frontal sections of the hippocampus $(50 \mu \mathrm{m})$ were cut with a vibratome and washed in PB. After a blocking step to reduce unspecific staining $(10 \%$ normal goat serum), serial sections of each brain were incubated in antibody solutions containing antibodies NC-1 and NC-2. Every seventh section was used for AChE histochemistry (see below). Free-floating sections were incubated for $2 \mathrm{~d}$ at $4^{\circ} \mathrm{C}$ in the primary antibody solutions (NC-1, 1:5000 or NC-2, 1:5000, in 1\% normal goat serum and $0.1 \% \mathrm{NaN}_{3}$ in $0.1 \mathrm{M} \mathrm{PB}$ ). For light microscopy, the antibody solution also contained $0.5 \%$ Triton X-100. For the immunohistochemical detection of the primary antibodies, a secondary biotinylated antibody was used (1:250; $2 \mathrm{hr}$ at room temperature, biotinylated anti-rabbit; Vector Laboratories, Burlingame, $\mathrm{CA}$ ). After rinsing in $\mathrm{PB}$, the sections were incubated in the avidin-biotin-peroxidase complex (ABC Elite; Vector Laboratories) for $2 \mathrm{hr}$ at room temperature. After three subsequent washes, the sections were immersed in a 3,3' diaminobenzidine (DAB) solution $(0.05 \%$ DAB and $0.001 \% \mathrm{H}_{2} \mathrm{O}_{2}$ in $0.1 \mathrm{M} \mathrm{PB}, 5-10 \mathrm{~min}$ ). Sections were placed on gelatin-coated slides, dehydrated in ethanol, and mounted in Hypermount (Life Science International, Frankfurt, Germany). In control experiments without the primary antibody, no immunocytochemical staining was observed. Sections for electron microscopy were osmicated $\left(0.5 \% \mathrm{OsO}_{4}\right.$ in $\left.\mathrm{PB}, 30 \mathrm{~min}\right)$, dehydrated $(70 \%$ ethanol containing $1 \%$ uranyl acetate), and embedded between liquid release-coated slides and coverslips. Selected sections were reembedded in blocks, and ultrathin sections were collected on single-slot Formvar-coated copper grids were examined in a Philips electron microscope.

Acetylcholinesterase histochemistry. After a unilateral ECL, a dense band of AChE-positive fibers appears in the outer molecular layer of the fascia dentata on the side of the lesion (Fig. 1) (Lynch et al., 1972; Naumann et al., 1997). This fiber band reflects the sprouting of cholinergic septohippocampal fibers after ECL and is typical for complete EC lesions (Nadler et al., 1977). In the present study, it was used to control lesion quality and to demonstrate that sprouting does in fact occur in the region of neurocan expression. Sections were processed for AChE histochemistry using a modified Karnovsky-Roots protocol (Mesulam et al., 1987).

Nucleic acid probes for in situ hybridization. Restriction enzymes were purchased from Amersham Pharmacia Biotech. The digoxigenin (DIG) RNA labeling kit, RNA polymerases, transfer RNA (tRNA), blocking reagent, and alkaline phosphatase-coupled anti-DIG antibody (antiDIG-AP) used were obtained from Boehringer Mannheim (Mannheim, Germany). Salmon sperm DNA, dextransulfate, and Denhardt's solution were obtained from Biometra-Amresco (Göttingen, Germany). All other chemicals used were obtained from Sigma (Deisenhofen, Germany).

Digoxigenin-labeled neurocan cRNA probes were generated from a neurocan cDNA EcoRI/KpnI fragment covering the first 738 bases of the neurocan cDNA (GenBank accession number X84727) inserted into pBluescript KS (Stratagene, La Jolla, CA). This plasmid was linearized with either KpnI to serve as template for T7 RNA polymerase (sense) or EcoRI for T3 RNA polymerase (antisense), respectively. Subsequently, the restricted DNA was purified by phenol extraction and ethanol precipitation. In vitro transcription was performed with $1 \mu \mathrm{g}$ of plasmid template (50 $\mu \mathrm{l}$ reaction) in the presence of ATP, GTP, CTP, DIG-11UTP (Boehringer Mannheim), RNasin, transcription buffer, and T3 or T7 RNA polymerase for $2 \mathrm{hr}$ at $37^{\circ} \mathrm{C}$ according to the manufacturer's recommendations. The in vitro transcription was stopped by the addition of $5 \mu \mathrm{l}$ of $0.25 \mathrm{M}$ EDTA, and DIG-labeled RNA was purified by ethanol precipitation in the presence of $\mathrm{LiCl}$ and was resuspended in $40 \mu \mathrm{l}$ of diethylpyrocarbonate (DEPC)-treated $\mathrm{H}_{2} \mathrm{O}$. The yield of DIG-labeled cRNA was determined by dot blot analysis according to the Boehringer Mannheim manual. In general, the amount of DIG-labeled RNA synthesized in one transcription reaction was $20 \mu \mathrm{g}$. The neurocan digoxigeninlabeled cRNA probes ( 780 bases) were treated by alkaline hydrolysis to reduce its size to $\sim 250$ bases following standard protocols. The hydrolyzed transcripts were resuspended in DEPC-treated $\mathrm{H}_{2} \mathrm{O}$ at a concentration of $100 \mathrm{ng} / \mu \mathrm{l}$ and stored at $-20^{\circ} \mathrm{C}$ until further use.

In situ hybridization histochemistry. EC-lesioned animals were transcardially perfused with $4 \%$ paraformaldehyde in $0.1 \mathrm{M}$ PBS, $\mathrm{pH} 7.2$, for 20 $\min$. The brains were removed and post-fixed in the same fixative for $5 \mathrm{hr}$ at $4^{\circ} \mathrm{C}$, followed by cryoprotection in $20 \%$ sucrose in $0.1 \mathrm{M}$ PBS, pH 7.2, at $4^{\circ} \mathrm{C}$ overnight. Cryostat sections $(40 \mu \mathrm{m}$, coronal plane) of the hippocampus were prepared and collected in $2 \times$ SSC $(1 \times$ SSC is $0.15 \mathrm{M}$ $\mathrm{NaCl}$ and $0.015 \mathrm{M}$ sodium citrate, $\mathrm{pH}$ 7.0) in tissue culture dishes and rinsed once in the same buffer. Tissue sections were pretreated in a 1:1 mixture of $2 \times \mathrm{SSC} /$ hybridization buffer $(50 \%$ formamide, $4 \times \mathrm{SSC}, 50$ $\mathrm{mm} \mathrm{NaH}{ }_{2} \mathrm{PO}_{4}, 250 \mu \mathrm{g} / \mathrm{ml}$ heat-denatured salmon sperm DNA, $100 \mu \mathrm{g} / \mathrm{ml}$ 

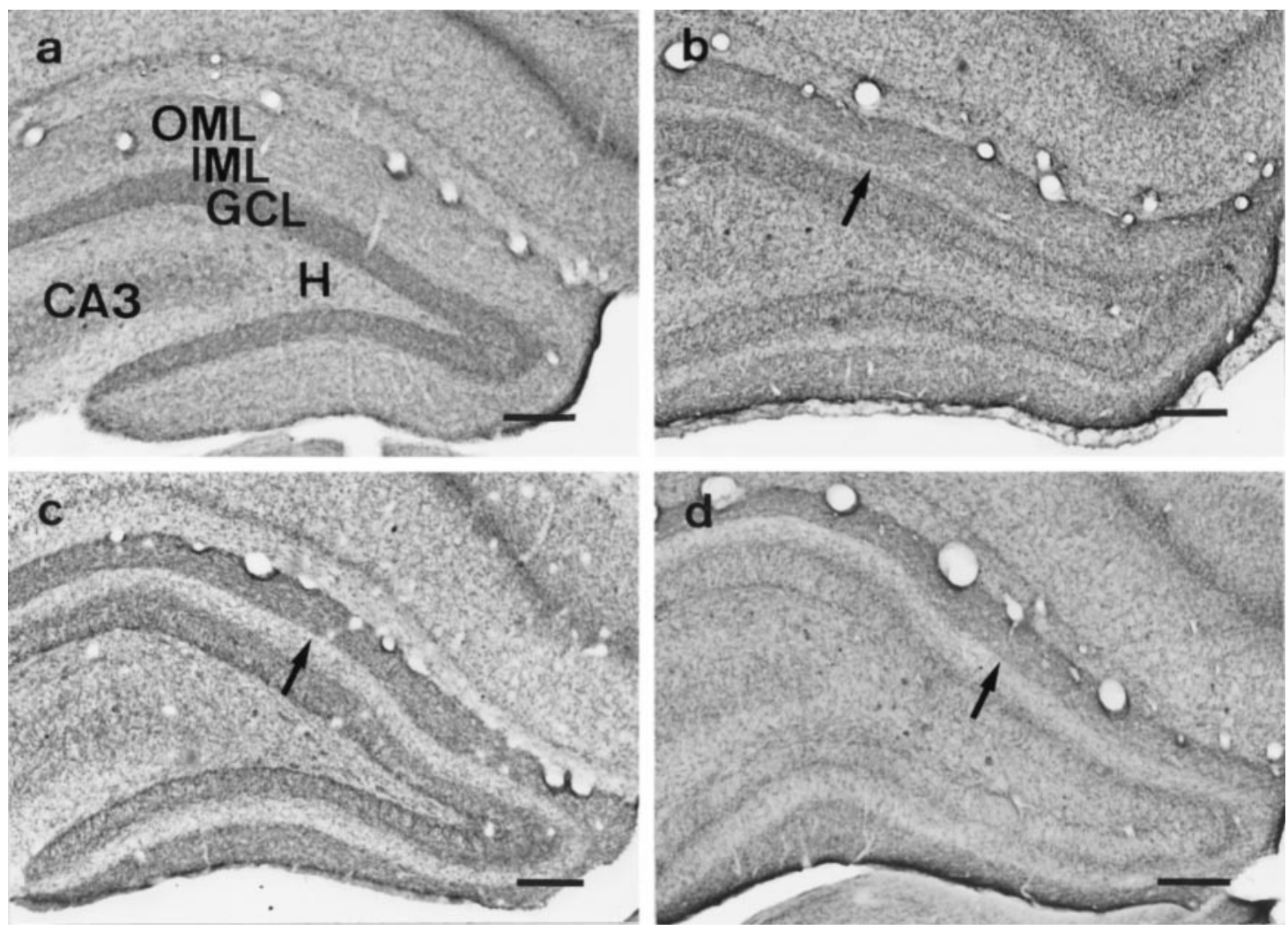

Figure 1. Cholinergic sprouting in the fascia dentata after entorhinal cortex lesion (acetylcholinesterase histochemistry). a, Control animal. The inner molecular layer $(I M L)$ and the outer molecular layer $(O M L)$ show a normal AChE staining pattern. GCL, Granule cell layer; $C A 3$, hippocampal subfield CA3; $H$, hilus. $b$, Ten days after ECL. AChE staining is increased in the outer molecular layer (arrow), indicating the sprouting of cholinergic fibers. $c$, Four weeks after ECL. A dense AChE-positive band is present in the outer molecular layer (arrow). Note that the cholinergic sprouting response occurs in the region of neurocan expression (compare Figs. 3, 6). $d$, Six months after ECL. The dense AChE-positive fiber band in the outer molecular layer persists (arrow). Scale bars: $a-d, 200 \mu \mathrm{m}$.

tRNA, $5 \%$ dextransulfate, and $1 \%$ Denhardt's solution) for 15 min and prehybridized in hybridization buffer for $60 \mathrm{~min}$ at $45^{\circ} \mathrm{C}$. Hybridization was performed in the same buffer including $100 \mathrm{ng} / \mathrm{ml}$ digoxigeninlabeled antisense or sense neurocan cRNA probes, respectively, at $45^{\circ} \mathrm{C}$ overnight. After hybridization, the brain sections were washed in $2 \times \mathrm{SSC}$ (two times for $15 \mathrm{~min}$ ) at room temperature, $2 \times \mathrm{SSC}$ and $50 \%$ formamide, $0.1 \times \mathrm{SSC}$ and $50 \%$ formamide for $15 \mathrm{~min}$ at $55^{\circ} \mathrm{C}$ each, and finally in $0.1 \times \mathrm{SSC}$ (two times for $15 \mathrm{~min}$ ) at $55^{\circ} \mathrm{C}$. Immunological detection of DIG-labeled hybrids with anti-DIG-AP (anti-digoxigenin antibody from sheep conjugated with alkaline phosphatase) was performed as recommended by the manufacturer (Boehringer Mannheim). Colorimetric detection was accomplished using nitroblue tetrazolium and 5-bromo-4chloro-3-indolylphosphate. Development of the color reaction was performed in the dark for $4 \mathrm{hr}$ and stopped by transfer into $10 \mathrm{~mm}$ Tris/ $\mathrm{HCl}$, $\mathrm{pH}$ 8.0, and $1 \mathrm{~mm}$ EDTA. Tissue sections were mounted onto glass slides, air-dried, and embedded in Moviol (Hoechst, Darmstadt, Germany), a water-based mounting medium.

Double labeling in situ hybridization-immunohistochemistry. In situ hybridization for neurocan mRNA was combined with immunohistochemistry for glial fibrillary acidic protein (GFAP), a marker for astrocytes. Tissue sections processed for in situ hybridization were extensively rinsed in TBS, $\mathrm{pH} 7.5$, for $1 \mathrm{hr}$, followed by incubation with a polyclonal GFAP antibody (1:500; Dako, Hamburg, Germany) in the presence of $1 \%$ NGS and TBS at $4^{\circ} \mathrm{C}$ overnight. After three washes (15 min each) with TBS, sections were exposed to the secondary biotinylated anti-rabbit antibody (Vector Laboratories) diluted 1:250 in TBS for $2 \mathrm{hr}$ at room temperature. Bound antibodies were detected by the indirect immunoperoxidase method using the $\mathrm{ABC}$ Elite kit (Vector Laboratories) and $\mathrm{DAB} / \mathrm{H}_{2} \mathrm{O}_{2}$ following the manufacturer's recommendations. Sections were mounted onto glass slides, air-dried, and coverslipped with Kaiser's glycerol gelatin (Merck, Darmstadt, Germany).

\section{RESULTS}

\section{Western blots against neurocan}

To ensure the specificity of the antisera, Western blots with crude tissue extracts from brain (Fig. 2, lanes $A-C$ ) and liver (Fig. 2, lanes $D-F$ ) were performed. The Western blot with the NC-1 serum and with soluble and detergent solubilized proteins from brain and liver homogenates shows the characteristic 150 and 250 $\mathrm{kDa}$ core protein bands of neurocan in the chondroitinase-treated soluble brain protein fraction (Fig. $2 a$, lane $B$ ), but not in the same fraction without treatment (Fig. $2 a$, lane $A$ ). The lack of recognizable differences in the corresponding lanes of the Coomassie blue staining (Fig. $2 b$, lanes $A, B$ ) shows that the proteoglycan represents a minor component of this protein fraction (the extra band in lane $B$ at $100 \mathrm{kDa}$ is derived from the enzyme preparation) and is indicative for the specificity of the serum. A specific signal was also obtained in a Western blot with the NC-2 serum (data not shown).

\section{Upregulation of neurocan in the fascia dentata after ECL}

Immunostaining with both antisera against neurocan gave identical results with a somewhat higher intensity of serum NC-1. The specificity of the antisera was confirmed by Western blot (Fig. 2). In control animals, animals $12 \mathrm{hr}$ after lesion, and animals $1 \mathrm{~d}$ after lesion, neurocan immunoreactivity was not above background levels (Fig. $3 a$ ). By 2 d after lesion, numerous neurocan- 


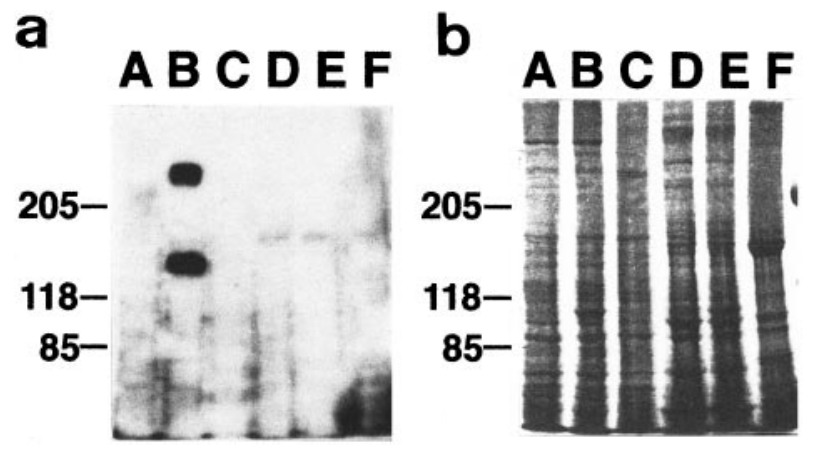

Figure 2. Western blot against neurocan. Protein samples from brain $(A-C)$ and liver $(D-F)$ of 3-week-old mice were used for a Western blot (a) or a Coomassie blue staining $(b)$. The TBS-soluble proteins $(A, B, D$, $E)$ were either treated with chondroitin-ABC-lyase $(B, E)$ or with buffer without the enzyme $(A, D)$. Lanes $C$ and $F$ represent consecutive Triton $\mathrm{X}-100$ extracts of the TBS-insoluble material. $a$ illustrates a Western blot with anti-neurocan serum (NC-1). The characteristic 150 and $250 \mathrm{kDa}$ core protein bands of neurocan can be seen in the chondroitinase-treated soluble brain protein fraction (lane $B$ ) but not in the same fraction without treatment (lane $A$ ). $b$ demonstrates that the proteoglycan represents a minor component of this protein fraction.

immunopositive cells could be detected in the fascia dentata (Fig. $3 b$ ). Most of these cells were located in the denervated outer molecular layer, although some cells could also be observed in the inner molecular layer and hilus. At higher magnification, these cells could be identified as astrocytes on the basis of their morphology (Fig. 3b, inset). By $4 \mathrm{~d}$ after lesion, the cellular staining pattern had disappeared. A dense neurocan immunostaining was found throughout the outer molecular layer, whereas the inner molecular layer was unstained. An increased labeling for neurocan was also observed subjacent to the granule cell layer (Fig. $3 c$ ). Neurocan immunolabeling in the outer molecular layer and hilus appeared to increase and seemed to be strongest $10 \mathrm{~d}, 14 \mathrm{~d}$ (Fig. $3 d$ ), and 4 weeks (Fig. 3e) after lesion. At all of these time points, the sharp border between the neurocan-rich outer molecular layer and the neurocan-poor inner molecular layer was maintained (Fig. 3f). By 6 months after lesion, neurocan was still present in the outer molecular layer and the hilar area, although the general level of immunostaining was somewhat weaker (Fig. $3 g$ ). To demonstrate that neurocan is present in the extracellular matrix compartment of the fascia dentata after ECL, electron microscopy was used. The outer molecular layer of an animal $14 \mathrm{~d}$ after lesion was analyzed in more detail (Fig. 4), and DAB immunoprecipitate was found in the extracellular matrix of these animals. Typically, DAB immunolabeling was found around axon terminals, dendrites, as well as glial processes located in the neuropil. No preferential deposition of neurocan around the basal lamina of blood vessels was observed.

The fascia dentata contralateral to the lesion site showed only a very slight upregulation of neurocan. No immunolabeling could be observed before $4 \mathrm{~d}$ after lesion. At 4 (Fig. 5a), 10, and 14 (Fig. $5 b) \mathrm{d}$, and 4 weeks after lesion, neurocan immunoreactivity in the outer molecular layer of the fascia dentata was barely above background levels, and only weak labeling was observed subjacent to the granule cells. No cellular labeling could be seen at any time point.

To control for unspecific staining, some sections were incubated without either primary or secondary antibody. No staining was observed under these conditions.

\section{Neurocan mRNA is strongly expressed in the denervated fascia dentata after ECL}

In situ hybridization for neurocan mRNA revealed no labeling in control animals (Fig. 6a) and in sham-operated animals (Fig. 6b). At $1 \mathrm{~d}$ after lesion, a strong cellular labeling for neurocan mRNA was observed in the denervated fascia dentata (Fig. 6c). The majority of neurocan mRNA-positive cells were located in the outer molecular layer, although some neurocan mRNA-positive cells were also observed in the inner molecular layer, granule cell layer, and hilus (Fig. 6c). At $4 \mathrm{~d}$ after lesion, the in situ hybridization signal for neurocan mRNA was strongest (Fig. $6 e, f$ ). The hybridization signal was located in the soma and in the proximal processes of the neurocan-expressing cells (Fig. $6 f$ ). At $6 \mathrm{~d}$ after lesion, no labeling for neurocan mRNA could be observed (Fig. $6 d)$. The sense controls were completely devoid of any hybridization signal at all time points (data not shown).

The fascia dentata contralateral to the lesion site showed changes in neurocan mRNA expression that were similar to but much weaker than those observed on the side ipsilateral to the lesion. Neurocan mRNA was expressed in the denervated outer molecular layer by day 1 after lesion (Fig. 5c) and was already decreased by day 4 after lesion (Fig. $5 d$ ). By day 6 after lesion, no neurocan mRNA signal could be detected in the contralateral fascia dentata.

\section{Neurocan mRNA-expressing cells after ECL are astrocytes}

After ECL, a strong astrocytic reaction occurs in the outer molecular layer of the fascia dentata (Gall et al., 1979). Astrocytes migrate into the denervated outer molecular layer, hypertrophy, and increase their GFAP expression (Gall et al., 1979; Steward et al., 1990, 1993). The pattern of neurocan mRNA expression that was observed after ECL and the immunocytochemical data strongly suggested that the neurocan mRNA-expressing cells are astrocytes. For this reason, double labeling for neurocan mRNA (in situ hybridization) and GFAP (immunohistochemistry) were used to identify the neurocan mRNA-expressing cells in the denervated outer molecular layer (Fig. 7). The colocalization of the two signals could readily be distinguished because the blue neurocan mRNA signal was primarily confined to the cytoplasm of the astrocytes, whereas the GFAP immunoreactivity localized mainly in the processes (Fig. 7c). This strategy revealed that all neurocan mRNA-positive cells in the outer molecular layer were GFAP-positive and that most, if not all, astrocytes were also neurocan mRNA-positive (Fig. 7b,c). Similarly, the few neurocan mRNA-expressing cells found in the inner molecular layer were astrocytes (Fig. 7b). Most of these cells have long GFAP-positive processes that reach the denervated outer molecular layer, whereas the somata exhibiting the hybridization signal for neurocan are located in the inner molecular layer. This is a characteristic reaction of astrocytes located in the inner molecular layer in this lesioning paradigm (Lee et al., 1997).

\section{Neurocan mRNA expression is unlikely to be caused by epileptiform activity}

Electrolytic lesions in the hippocampal area may have an epileptogenic effect because of the deposition of iron (Dasheiff and McNamara, 1982; Campbell et al., 1984). This epileptiform activity may influence gene expression after ECL in the early postlesional period (Kelley and Steward, 1996a,b). To avoid the deposition of iron, ECLs were also made with a glass knife. The pattern of neurocan mRNA expression that was observed in the 

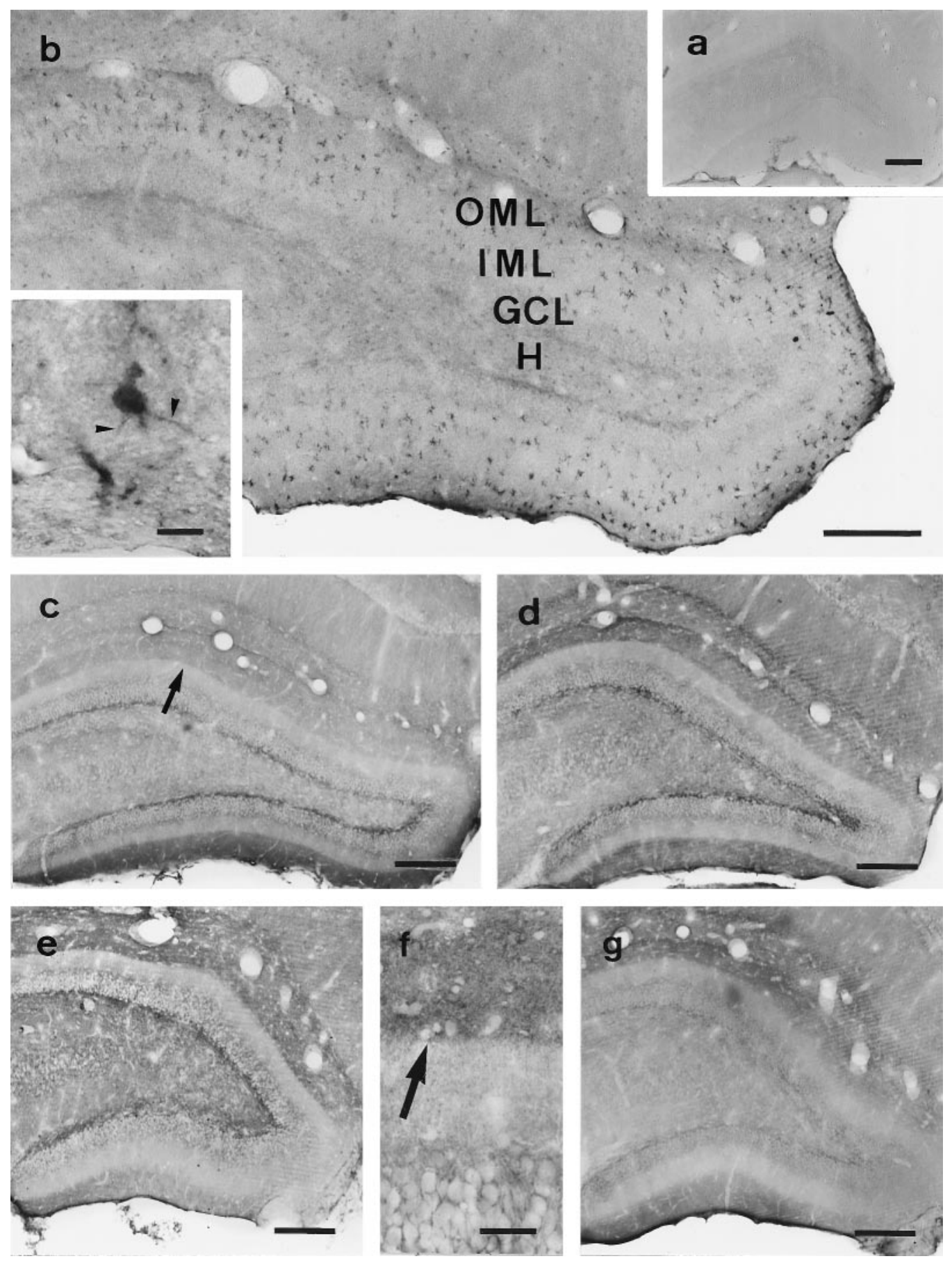

Figure 3. Upregulation of neurocan in the denervated fascia dentata after ECL. $a$, Control animal stained for neurocan. The fascia dentata is unstained. $b$, Two days after ECL. A large number of neurocan-immunoreactive cells has appeared in the outer molecular layer of the fascia dentata. The inset shows a neurocan-positive cell at higher magnification. The morphology of this cell is typical for an astroglial cell. Arrowheads point to the characteristic astroglial processes. $O M L$, Outer molecular layer; $I M L$, inner molecular layer; $G C L$, granule cell layer; $H$, hilus. $c$, Four days after ECL. Neurocan immunoreactivity is present throughout the denervated outer molecular layer (arrow) and subjacent to the granule cell layer. Single immunoreactive cells cannot be distinguished at this time point. $d$, Fourteen days after ECL. A dense neurocan-immunoreactive band is visible in the denervated outer molecular layer. $e$, Four weeks after ECL. Immunoreactivity for neurocan remains high in the outer molecular layer and hilus. A portion of the outer molecular layer is shown at higher magnification in $f . f$, Portion of the outer molecular layer of the fascia dentata shown in $e$. Note that the neurocan-rich outer molecular layer forms a sharp border against the neurocan-poor inner molecular layer. $g$, Six months after ECL. Staining for neurocan has slightly decreased compared with earlier time points but remains considerably above control levels $(a)$. Scale bars: $a, c, d, e, g, 250 \mu \mathrm{m} ; b, 200 \mu \mathrm{m} ; f, 40 \mu \mathrm{m} ;$ inset in $b, 10 \mu \mathrm{m}$.

fascia dentata ipsilateral, as well as contralateral, to the lesion side was identical to the pattern observed using the stainless steel knife of our electrocoagulator (see Materials and Methods). In addition, no neurocan hybridization signal was observed in the fascia dentata after sham operations, which may also induce epileptiform activity in the damaged brain. Thus, neurocan mRNA synthesis in the denervated hippocampus is unlikely to be caused by epileptiform activity. 


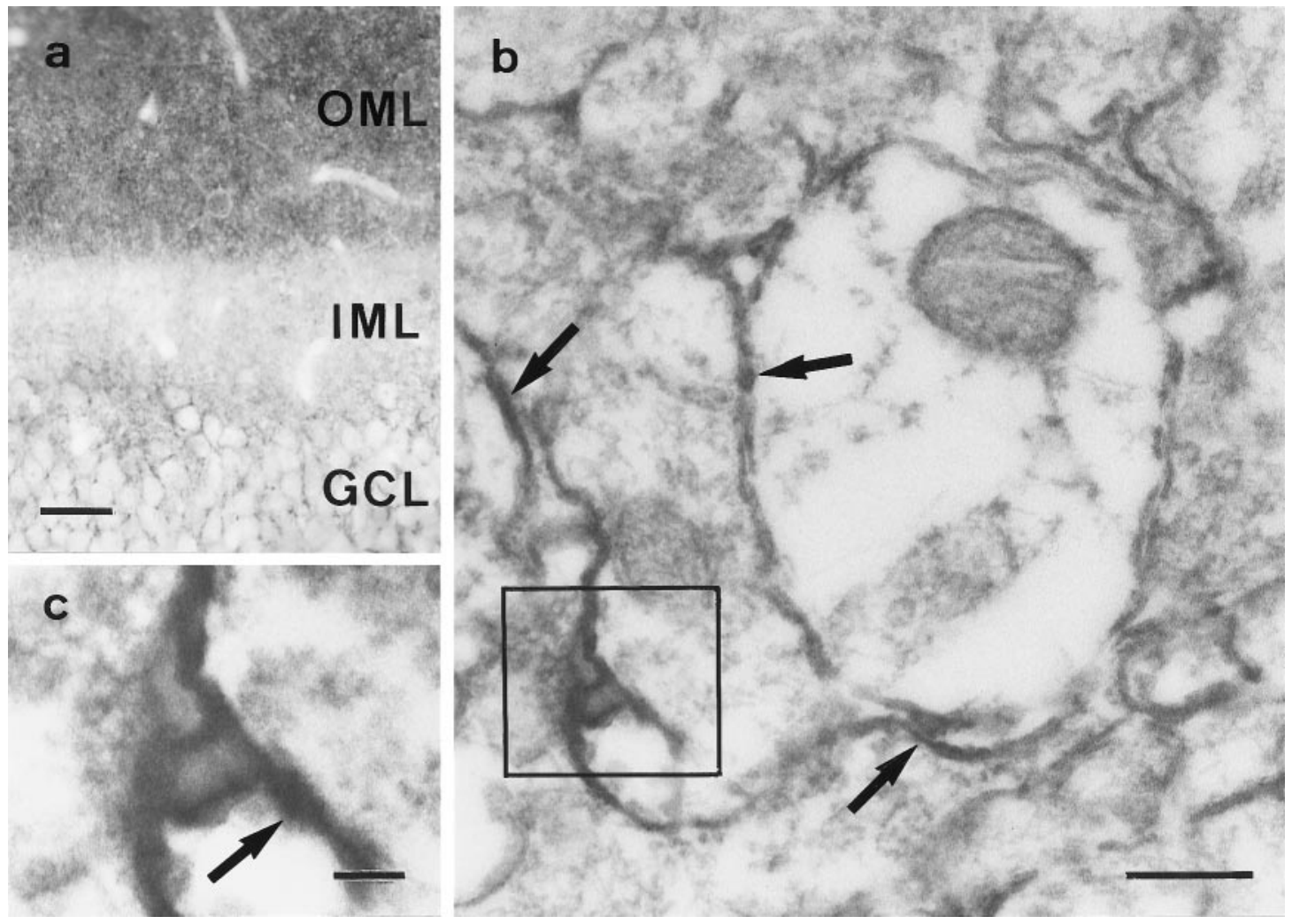

Figure 4. Neurocan is found in the extracellular matrix of the denervated outer molecular layer. $a$, Light micrograph of a portion of the fascia dentata $14 \mathrm{~d}$ after lesion. The outer molecular layer $(O M L)$ is strongly neurocan-immunopositive. $I M L$, Inner molecular layer; $G C L$, granule cell layer. $b$, Electron micrograph of the outer molecular layer illustrated in $a$. Immunoprecipitate can be found in the extracellular matrix surrounding various profiles in the neuropil (arrows). Framed area shown at higher magnification in $c$. $c$. Higher magnification of the framed area in $b$. The extracellular matrix is neurocan-immunoreactive (arrow). Scale bars: $a, 30 \mu \mathrm{m} ; b, 0.5 \mu \mathrm{m} ; c, 0.1 \mu \mathrm{m}$.

\section{Neurocan and neurocan mRNA are expressed by astrocytes at the lesion site}

In the vicinity of the lesion site neurocan and neurocan mRNA were found to be upregulated (data not shown). Neurocan immunohistochemistry demonstrated numerous neurocan-immunopositive astrocytes surrounding the lesion cavity $2 \mathrm{~d}$ after lesion. At later time points, the ECM surrounding the lesion site was diffusely immunopositive and remained so up to 6 months after lesion. Neurocan mRNA expression was strongest in the area immediately surrounding the lesion cavity with a time course of mRNA expression similar to that observed in the fascia dentata, i.e., neurocan mRNA was detected $1 \mathrm{~d}$ after lesion and disappeared by $6 \mathrm{~d}$ after lesion. Double labeling for neurocan mRNA and GFAP demonstrated that the neurocan mRNA-synthesizing cells are astrocytes. Thus, the spatial and temporal expression pattern of neurocan and its mRNA at the lesion site was similar to that seen in the denervated fascia dentata.

\section{DISCUSSION}

To test whether the brain-specific CSPG neurocan is reexpressed in areas of axonal sprouting after brain injury, neurocan and neurocan mRNA expression were analyzed after ECL. During the first days after lesion, neurocan and neurocan mRNA were upregulated in the denervated outer molecular layer of the fascia dentata. In contrast to the situation during development when neurocan is expressed by neurons, neurocan was found to be exclusively synthesized by reactive astrocytes. After some neces- sary methodological considerations, we will discuss our data with regard to the axonal sprouting process after ECL.

\section{Methodological considerations}

Immunocytochemical studies that use polyclonal antisera against a specific CSPG have to be interpreted with some caution. Therefore, we have (1) tested the specificity of the antisera with Western blots of crude tissue extracts (Fig. 2), (2) used two independently generated polyclonal antisera against neurocan that gave us identical results, and (3) corroborated the immunocytochemical results with in situ hybridization. Thus, we are convinced that our immunocytochemical data of the fascia dentata, obtained after ECL, reflect the upregulation of neurocan.

\section{Brain lesion induces astrocytic neurocan expression}

During development, neurocan is widely expressed in the rat brain, synthesized, and released predominantly by neurons (Engel et al., 1996; Meyer-Puttlitz et al., 1996). Neurocan expression reaches a peak during the first week postnatally and is rapidly downregulated thereafter (Milev et al., 1998). From the second postnatal month on, almost every neurocan molecule in rat brain appears to be proteolytically processed in the central mucin-like part of the molecule (Rauch et al., 1991; Oohira et al., 1994; Matsui et al., 1998).

After ECL, neurocan is strongly expressed in the fascia dentata of adult rats. Very much to our surprise, the pattern of neurocan expression in the denervated outer molecular layer (Fig. 6), the morphology of neurocan immunolabeled cells (c.f. Fig. 3b, inset), 

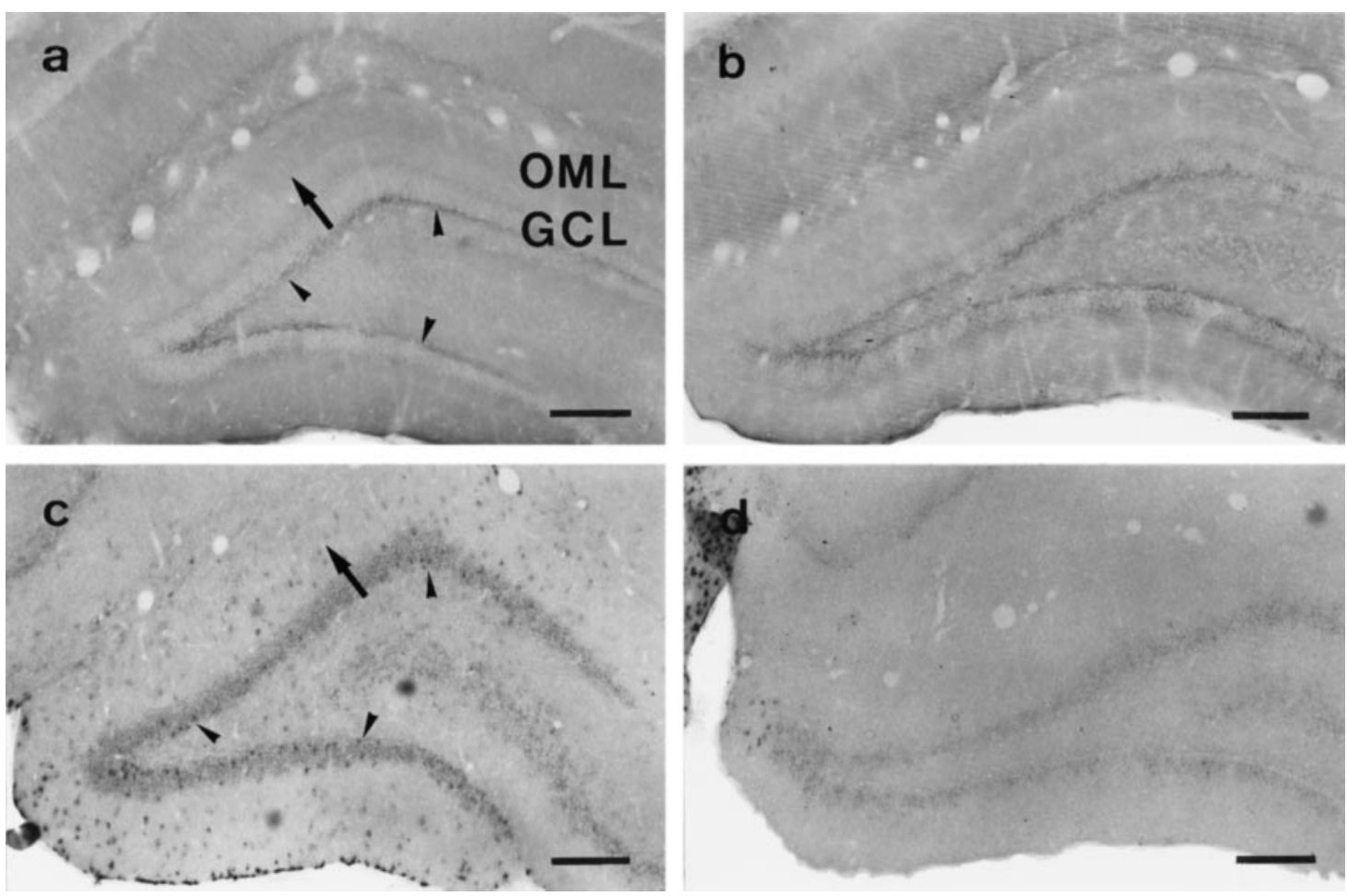

Figure 5. Neurocan immunostaining and neurocan mRNA expression in the contralateral fascia dentata. $a$, Neurocan immunohistochemistry $4 \mathrm{~d}$ after lesion. Immunostaining for neurocan is detectable subjacent to the granule cell layer (GCL; arrowheads). The outer molecular layer $(O M L ;$ arrow) is only very lightly labeled. $b$, Neurocan immunohistochemistry $14 \mathrm{~d}$ after lesion. The pattern of immunostaining is similar to that observed $4 \mathrm{~d}$ after lesion $(a)$. Neurocan immunostaining is most prominent subjacent to the granule cell layer, and the outer molecular layer is only very lightly labeled. $c$, In situ hybridization for neurocan mRNA $1 \mathrm{~d}$ after lesion. Neurocan mRNA labeling can be observed in the molecular layer (arrow) and to some extent subjacent to the granule cell layer (arrowheads). $d$, In situ hybridization for neurocan mRNA $4 \mathrm{~d}$ after lesion. With the exception of a few cells that remain visible at the crest of the fascia dentata, neurocan mRNA expression has disappeared. Scale bars, $a-d, 250 \mu \mathrm{m}$.

as well as the combination of in situ hybridization for neurocan and immunohistochemistry for GFAP (Fig. 7), demonstrated that astrocytes synthesize neurocan. Thus, the site of neurocan synthesis changes from neurons during the period of brain development to astroglial cells after injury of the adult brain, suggesting that astrocytes are capable of switching on a completely new set of genes after denervation. Oohira and colleagues (1994) reported that neurocan was synthesized by pure cultures of mature astrocytes. Whereas this might reflect a situation similar to the denervated state in tissue, the recent observation that the neurocan cleavage fragment neurocan- 130 is present in glial processes of adult rats (Matsui et al., 1998), indicates that, at later developmental stages, glial expression of neurocan might not be uncommon. Also, several other ECM molecules are known that are expressed by astrocytes as well as neurons (Ferhat et al., 1996a,b; Nakic et al., 1996; Yamaguchi, 1996; Deller et al., 1997; Yamada et al., 1997). In the light of these data, our results may also be interpreted as an example for the differential regulation of the neurocan gene during development and after lesion. During early development, neurons and only a small number of astrocytes express neurocan. After ECL, only astrocytes but not neurons are able to reexpress neurocan.

\section{Neurocan upregulation after lesion leads to long-lasting changes in ECM composition}

Within the first days after lesion, neurocan and its mRNA are found in astrocytes. Shortly thereafter, neurocan mRNA expression is downregulated, the cellular localization of neurocan disappears, and the ECM of the outer molecular layer becomes diff usely neurocan-immunopositive. These data are compatible with an astrocytic synthesis of neurocan and a subsequent release of the molecule into the ECM (Rauch et al., 1991, 1992; Oohira et al., 1994). Interestingly, neurocan can still be detected in the fascia dentata by half a year after lesion, whereas detectable neurocan synthesis only occurs during the first postlesional week. This demonstrates that neurocan has an extremely long half-life within the ECM of the adult brain. These data are in line with an earlier report that showed that CSPGs remain in brain ECM for over 1 year after lesion (Lips et al., 1995). In addition, the presence of neurocan within the outer molecular layer 6 months after lesion proves that the denervated outer molecular layer exhibits long-lasting changes in the composition of the ECM. The denervated zone does not revert to its prelesion state, even after the reorganization of the fascia dentata after ECL is complete (see below) (for review, see Deller and Frotscher, 1997).

Neurocan and its mRNA are also upregulated in the hilus of the fascia dentata. This region also receives some entorhinal input (Wyss, 1981; Deller et al., 1996a; Deller, 1998), and the degeneration of these fibers could explain the increase of neurocan mRNA and neurocan in the hilus.

\section{Neurocan is reexpressed in the zone of axonal sprouting}

After ECL, $80-90 \%$ of the synapses in the outer molecular layer of the fascia dentata are lost (Matthews et al., 1976a; Steward and Vinsant, 1983). In response to this massive denervation, surviving axons form new collaterals and reinnervate the fascia dentata within the first 4 weeks after lesion (Matthews et al., 1976b; 

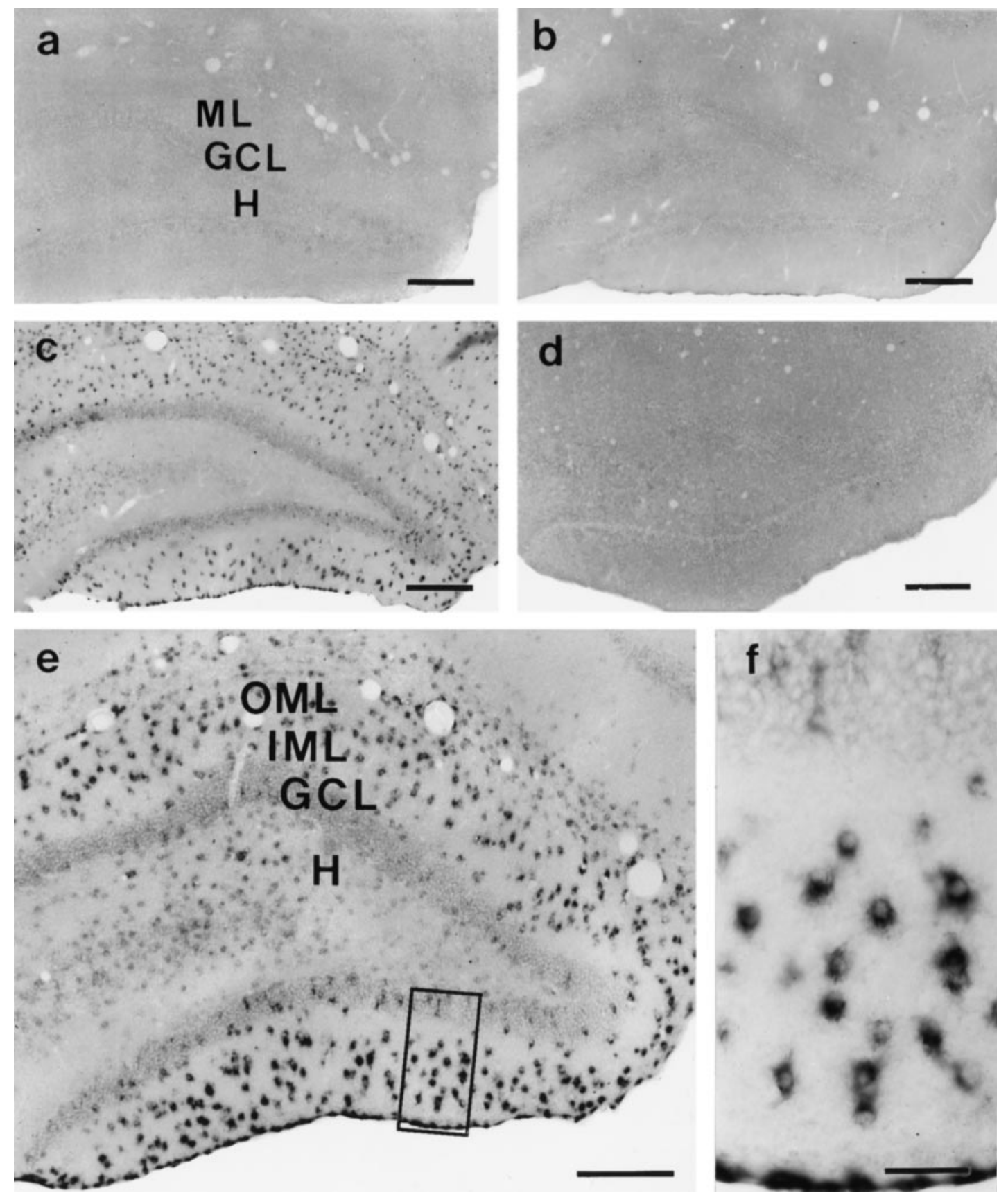

Figure 6. Neurocan mRNA expression in the denervated fascia dentata. $a$, Control animal. No labeling for neurocan mRNA can be observed. $M L$, Molecular layer; $G C L$, granule cell layer; $H$, hilus. $b$, Sham-operated animal. Note absence of staining. $c$, Neurocan mRNA expression in the fascia dentata $1 \mathrm{~d}$ after ECL. Neurocan mRNA-positive cells are observed in large numbers in the outer molecular layer of the dentate gyrus. Occasionally, neurocan mRNA-positive cells are found in the inner molecular layer, granule cell layer, and hilus. $d$, Neurocan mRNA expression in the fascia dentata $6 \mathrm{~d}$ after ECL. Neurocan mRNA expression has disappeared. $e$, Neurocan mRNA expression in the fascia dentata $4 \mathrm{~d}$ after lesion. Many cellular profiles are observed in the outer molecular layer of the fascia dentata and in stratum lacunosum-moleculare of CA1 and CA3. Framed area shown at higher magnification in $f$. $O M L$, Outer molecular layer; $I M L$, inner molecular layer. $f$, Higher magnification of framed area in $e$. Heavily labeled cells are restricted to the outer molecular layer. Scale bars: $a-d, 250 \mu \mathrm{m} ; e, 200 \mu \mathrm{m} ; f, 40 \mu \mathrm{m}$.

Steward and Vinsant, 1983). During this time period, the ECM provides the substrate through which the sprouting axons grow, and changes in the composition of the ECM are likely to influence the sprouting process. In the present study, we have observed that the ECM of the denervated outer molecular layer is enriched with neurocan during the time period of axonal growth. Although neurocan-rich substrate inhibits axonal growth in vitro (see introductory remarks), these observations demonstrate that neurocan-rich ECM does not inevitably inhibit axonal growth in vivo.

Our observations are in line with other in vivo studies that reported the expression of neurocan in regions of active axonal growth during development (for review, see Pearlman and Sheppard, 1996) (Bicknese et al., 1994; Miller et al., 1995; Engel et al., 1996; Meyer-Puttlitz et al., 1996; Fukuda et al., 1997). In these brain areas, growth-promoting cell adhesion molecules are abun- 

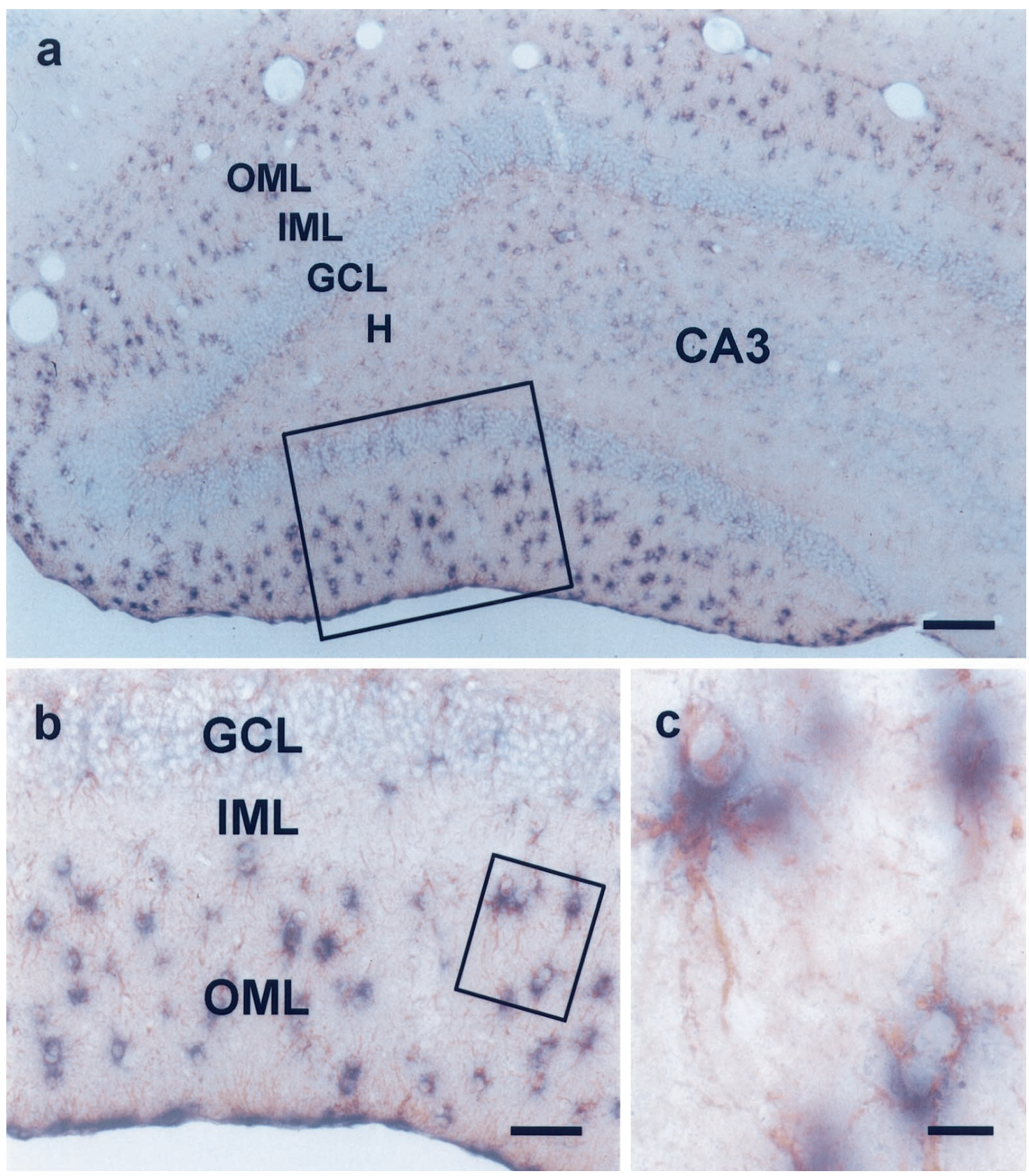

Figure 7. Reactive astrocytes reexpress neurocan mRNA after ECL. $a$, Fascia dentata $4 \mathrm{~d}$ after entorhinal cortex lesion. This section was double labeled for GFAP (immunohistochemistry) and neurocan mRNA (in situ hybridization). Framed area shown at higher magnification in $b$. OML, Outer molecular layer; $I M L$, inner molecular layer; $G C L$, granule cell layer; $H$, hilus; $C A 3$, hippocampal subfield CA3. $b$, Higher magnification of framed area in $a$. Neurocan mRNA-positive cells are present within the denervated outer molecular layer. Framed area shown at higher magnification in $c$. $c$, Higher magnification of framed area in $b$. Several double-labeled astroglial cells are visible. Immunostaining for GFAP (brown) identifies astrocytes and labels their somata and proximal processes. In situ hybridization for neurocan mRNA (blue) identifies neurocan mRNA-expressing cells. Note that all neurocan mRNA-expressing cells are astrocytes (see $b$ ). Scale bars: $a, 100 \mu \mathrm{m} ; b, 40 \mu \mathrm{m} ; c, 10 \mu \mathrm{m}$.

dant and axonal growth occurs despite the presence of neurocan (Fukuda et al., 1997). For this reason, it was suggested that the biological effects of neurocan on growing axons depend on the relative concentration as well as the order of assembly of various ECM and cell adhesion molecules (Grumet et al., 1996; Margolis and Margolis, 1997). When expressed in regions containing low levels of adhesion molecules, neurocan may act as a barrier to axonal growth. However, when expressed in regions containing high levels of adhesion molecules, neurocan may allow axonal extension to occur. After ECL, the embryonic form of N-CAM
(Miller et al., 1994), growth-promoting isoforms of tenascin-C (Deller et al., 1997), the growth-promoting proteoglycan DSD-1 (Deller et al., 1997), and integrin adhesion molecules (Hailer et al., 1997) are upregulated in the denervated outer molecular layer. Thus, the denervated zone of the denervated fascia dentata contains many growth-promoting molecules that can balance growth-inhibiting effects of neurocan on sprouting axons.

What may be the role of neurocan during the sprouting process if it does not promote axonal growth? A recent study, which focused on the role of CSPGs during axonal regeneration (Davies 
et al., 1999), suggests that these molecules play a role in the formation of local axonal branches. Regenerating axons that grow inwards from the edge of a lesion grow up a gradient of increasingly CSPG-rich ECM. These axons become more branched as they enter more deeply into the CSPG-rich environment before coming to a complete stop at the center of the lesion. These observations indicate that increasing concentrations of CSPGs can promote the formation of local sprouts before acting as a stop signal for elongating axons (Davies et al., 1999). In this line, a moderate upregulation of neurocan in the denervated outer molecular layer could contribute to the branching of sprouting axons, and, therefore, to the formation of new axonal collaterals within the denervated zone.

\section{Neurocan may act to maintain laminar boundaries after ECL}

Earlier studies suggested that neurocan expressed in regions of axonal growth may act to define boundaries for growing fibers during development (Bicknese et al., 1994; Katoh-Semba et al., 1995; Miller et al., 1995). If neurocan plays such a role during development, neurocan may act in a similar manner after ECL and may help to define the region in which sprouting occurs. In fact, neurocan is exclusively expressed in the denervated outer molecular layer, and a sharp border is formed against the neurocan-poor inner molecular layer of the fascia dentata (Fig. $3 f$ ). This distribution of neurocan correlates precisely with the laminar termination pattern of the sprouting fiber populations; surviving afferents that are normally present in the outer molecular layer sprout within this layer, whereas afferents that originate from the neurocan-poor inner molecular layer are unable to invade the denervated zone (Deller et al., 1996b; Deller and Frotscher, 1997; Frotscher et al., 1997). This correlation suggests that neurocan may contribute to the zonal reorganization of the fascia dentata after ECL and that neurocan may act to prevent the ingrowth of fibers not normally present in the outer molecular layer.

\section{REFERENCES}

Bicknese AR, Sheppard AM, O'Leary DD, Pearlman AL (1994) Thalamocortical axons extend along a chondroitin sulfate proteoglycan-enriched pathway coincident with the neocortical subplate and distinct from the efferent path. J Neurosci 14:3500-3510.

Campbell KA, Bank B, Milgram NW (1984) Epileptogenic effects of electrolytic lesions in the hippocampus: role of iron deposition. Exp Neurol 86:506-514.

Cotman CW, Nieto-Sampedro M, Harris EW (1981) Synapse replacement in the nervous system of adult vertebrates. Physiol Rev 61:684-784.

Dasheiff RM, McNamara JO (1982) Electrolytic entorhinal cortex lesions cause seizures. Brain Res 231:444-450.

Davies SJA, Fitch MT, Memberg ST, Hall AK, Raisman G, Silver J (1997) Regeneration of adult axons in white matter tracts of the central nervous system. Nature 390:680-683.

Davies SJA, Goucher DR, Doller C, Silver J (1999) Robust regeneration of adult sensory axons in degenerating white matter of the adult rat spinal cord. J Neurosci 19:5810-5822.

Deller T (1998) The anatomical organization of the rat fascia dentatanew aspects of laminar organization as revealed by anterograde tracing with phaseolus vulgaris-leucoagglutinin. Anat Embryol 197:89-103.

Deller T, Frotscher M (1997) Lesion-induced plasticity of central neurons: sprouting of single fibers in the rat hippocampus after unilateral entorhinal lesion. Prog Neurobiol 53:687-727.

Deller T, Frotscher M, Nitsch R (1995) Morphological evidence for the sprouting of inhibitory commissural fibers in response to the lesion of the excitatory entorhinal input to the rat dentate gyrus. J Neurosci 15:6868-6878.

Deller T, Martinez A, Nitsch R, Frotscher M (1996a) A novel entorhinal projection to the rat dentate gyrus: direct innervation of proximal dendrites and cell bodies of granule cells and GABAergic neurons. J Neurosci 16:3322-3333.

Deller T, Nitsch R, Frotscher M (1996b) Layer-specific sprouting of commissural fibers to the rat fascia dentata after unilateral entorhinal cortex lesion: a phaseolus vulgaris leucoagglutinin tracing study. Neuroscience 71:651-660.

Deller T, Haas CA, Naumann T, Joester A, Faissner A, Frotscher M (1997) Upregulation of astrocyte-derived tenascin-C correlates with neurite outgrowth in the rat dentate gyrus after unilateral entorhinal cortex lesion. Neuroscience 81:829-846.

Engel M, Maurel P, Margolis RU, Margolis RK (1996) Chondroitin sulfate proteoglycans in the developing central nervous system. I. Cellular sites of synthesis of neurocan and phosphacan. J Comp Neurol 366:34-43.

Ferhat L, Chevassus-Au-Louis N, Jorquera J, Niquet J, Khrestchatisky M, Ben-Ari Y, Represa A (1996a) Transient increase of tenascin-C in immature hippocampus: astroglial and neuronal expression. J Neurocytol 25:53-66.

Ferhat L, Chevassus-Au-Louis N, Khrestchatisky M, Ben-Ari Y, Represa A (1996b) Seizures induce tenascin-C mRNA expression in neurons. J Neurocytol 25:535-546.

Friedlander DR, Milev P, Karthikeyan L, Margolis RK, Margolis RU, Grumet M (1994) The neuronal chondroitin sulfate proteoglycan neurocan binds to the neural cell adhesion molecules Ng-CAM/L1/NILE and N-CAM and inhibits neuronal adhesion and neurite outgrowth. J Cell Biol 125:669-680.

Frotscher M, Heimrich B, Deller T (1997) Sprouting in the hippocampus is layer-specific. Trends Neurosci 20:218-223.

Fukuda T, Kawano H, Ohyama K, Li HP, Takeda Y, Oohira A, Kawamura K (1997) Immunohistochemical localization of neurocan and L1 in the formation of thalamocortical pathways of developing rats. J Comp Neurol 382:141-152.

Gall C, Rose G, Lynch G (1979) Proliferative and migratory activity of glial cells in the partially deafferented hippocampus. J Comp Neurol 183:539-550.

Grumet M, Milev P, Sakurai T, Karthikeyan L, Bourdon M, Margolis RK, Margolis RU (1994) Interactions with tenascin and differential effects on cell adhesion of neurocan and phosphacan, two major chondroitin sulfate proteoglycans of nervous tissue. J Biol Chem 269:12142-12146.

Grumet M, Friedlander DR, Sakurai T (1996) Functions of brain chondroitin sulfate proteoglycans during development: interactions with adhesion molecules. Perspect Dev Neurobiol 3:319-330.

Hailer NP, Bechmann I, Heizmann S, Nitsch R (1997) Adhesion molecule expression on phagocytic microglial cells following anterograde degeneration of perforant path axons. Hippocampus 7:341-349.

Höke A, Silver J (1996) Proteoglycans and other repulsive molecules in glial boundaries during development and regeneration of the nervous system. Prog Brain Res 108:149-163.

Katoh-Semba R, Matsuda M, Kato K, Oohira A (1995) Chondroitin sulphate proteoglycans in the rat brain: candidates for axon barriers of sensory neurons and the possible modification by laminin of their actions. Eur J Neurosci 7:613-621.

Kelley MS, Steward O (1996a) The process of reinnervation in the dentate gyrus of adult rats: physiological events at the time of the lesion and during the early postlesion period. Exp Neurol 139:73-82.

Kelley MS, Steward O (1996b) The role of postlesion seizures and spreading depression in the upregulation of glial fibrillary acidic protein mRNA after entorhinal cortex lesions. Exp Neurol 139:83-94.

Lee M-Y, Deller T, Kirsch M, Frotscher M, Hofmann H-D (1997) Differential regulation of ciliary neurotrophic factor (CNTF) and CNTF receptor $\alpha$ expression in astrocytes and neurons of the fascia dentata after entorhinal cortex lesion. J Neurosci 17:1137-1146.

Lips K, Stichel CC, Müller HW (1995) Restricted appearance of tenascin and chondroitin sulphate proteoglycans after transection and sprouting of adult rat postcommissural fornix. J Neurocytol 24:449-464.

Lynch G, Matthews DA, Mosko S, Parks T, Cotman CW (1972) Induced acetylcholinesterase-rich layer in rat dentate gyrus following entorhinal lesions. Brain Res 42:311-318.

Margolis RU, Margolis RK (1997) Chondroitin sulfate proteoglycans as mediators of axon growth and pathfinding. Cell Tissue Res 290:343-348.

Matsui F, Nishizuka M, Yasuda Y, Aono S, Watanabe E, Oohira A (1998) Occurrence of a N-terminal proteolytic fragment of neurocan, 
not a C-terminal half, in a perineuronal net in the adult rat cerebrum. Brain Res 790:45-51.

Matthews DA, Cotman CW, Lynch G (1976a) An electron microscopic study of lesion-induced synaptogenesis in the dentate gyrus of the adult rat. I. Magnitude and time course of degeneration. Brain Res 115:1-21.

Matthews DA, Cotman CW, Lynch G (1976b) An electron microscopic study of lesion-induced synaptogenesis in the dentate gyrus of the adult rat. II. Reappearance of morphologically normal synaptic contacts. Brain Res 115:23-41.

Mesulam MM, Geula C, Moràn MA (1987) Anatomy of cholinesterase inhibition in Alzheimer's disease: effect of physostigmine and tetrahydroaminoacridine on plaques and tangles. Ann Neurol 22:683-691.

Meyer-Puttlitz B, Junker E, Margolis RU, Margolis RK (1996) Chondroitin sulfate proteoglycans in the developing central nervous system. II. Immunocytochemical localization of neurocan and phosphacan. J Comp Neurol 366:44-54.

Milev P, Maurel P, Haring M, Margolis RK, Margolis RU (1996) TAG1/axonin-1 is a high-affinity ligand of neurocan, phosphacan/proteintyrosine phosphatase-zeta/beta, and N-CAM. J Biol Chem 271:15716-15723.

Milev P, Maurel P, Chiba A, Mevissen M, Popp S, Yamaguchi Y, Margolis RK, Margolis RU (1998) Differential regulation of expression of hyaluronan-binding proteoglycans in developing brain: aggrecan, versican, neurocan, and brevican. Biochem Biophys Res Commun 207-212.

Miller B, Sheppard AM, Bicknese AR, Pearlman AL (1995) Chondroitin sulfate proteoglycans in the developing cerebral cortex: the distribution of neurocan distinguishes forming afferent and efferent axonal pathways. J Comp Neurol 355:615-628.

Miller PD, Styren SD, Lagenaur CF, DeKosky ST (1994) Embryonic neural cell adhesion molecule (N-CAM) is elevated in the denervated rat dentate gyrus. J Neurosci 14:4217-4225.

Nadler JV, Cotman CW, Lynch G (1977) Histochemical evidence of altered development of cholinergic fibers in the rat dentate gyrus following lesions. I. Time course after complete unilateral entorhinal lesion at various ages. J Comp Neurol 171:561-588.

Nakic M, Mitrovic N, Sperk G, Schachner M (1996) Kainic acid activates transient expression of tenascin-C in the adult rat hippocampus. J Neurosci Res 44:355-362.

Naumann T, Deller T, Bender R, Frotscher M (1997) 192 IgG-saporininduced loss of cholinergic neurons in the septum abolishes cholinergic sprouting after unilateral entorhinal lesion in the rat. Eur J Neurosci 9:1304-1313.

Oohira A, Matsui F, Watanabe E, Kushima Y, Maeda N (1994) Developmentally regulated expression of a brain specific species of chondroitin sulfate proteoglycan, neurocan, identified with a monoclonal antibody $1 \mathrm{G} 2$ in rat cerebrum. Neuroscience 60:145-157.

Pearlman AL, Sheppard AM (1996) Extracellular matrix in early cortical development. Prog Brain Res 108:117-134.
Raisman G (1969) Neuronal plasticity in the septal nuclei of the adult rat. Brain Res 14:25-48.

Rauch U (1997) Modeling an extracellular environment for axonal pathfinding and fasciculation in the cerebral nervous system. Cell Tissue Res 290:349-356.

Rauch U, Gao P, Janetzko A, Flaccus A, Hilgenberg L, Tekotte H, Margolis RK, Margolis RU (1991) Isolation and characterization of developmentally regulated chondroitin sulfate and chondroitin/keratan sulfate proteoglycans of brain identified with monoclonal antibodies. J Biol Chem 266:14785-14801.

Rauch U, Karthikeyan L, Maurel P, Margolis RU, Margolis RK (1992) Cloning and primary structure of neurocan, a developmentally regulated, aggregating chondroitin sulfate proteoglycan of brain. J Biol Chem 271:19536-19547.

Rauch U, Clement A, Retzler C, Fröhlich L, Fässler R, Göhring W, Faissner A (1997) Mapping of a defined neurocan binding site to distinct domains of tenascin-C. J Biol Chem 272:26905-26912.

Retzler C, Göhring W, Rauch U (1996) Analysis of neurocan structures interacting with the neural cell adhesion molecule N-CAM. J Biol Chem 271:27304-27310.

Steward O, Vinsant SL (1983) The process of reinnervation in the dentate gyrus of the adult rat: a quantitative electron microscopic analysis of terminal proliferation and reactive synaptogenesis. J Comp Neurol 214:370-386.

Steward O, Torre ER, Phillips L, Trimmer PA (1990) The process of reinnervation in the dentate gyrus of adult rats: time course of increases in mRNA for glial fibrillary acidic protein. J Neurosci 10:2373-2384.

Steward O, Kelley MS, Torre ER (1993) The process of reinnervation in the dentate gyrus of adult rats: temporal relationship between changes in the level of glial fibrillary acidic protein (GFAP) and GFAP mRNA in reactive astrocytes. Exp Neurol 124:167-183.

Stichel CC, Müller HW (1998) The CNS lesion scar: new vistas on an old regeneration barrier. Cell Tissue Res 294:1-9.

Tuttle R, Braisted JE, Richards LJ, O'Leary DD (1998) Retinal axon guidance by region-specific cues in diencephalon. Development 125:791-801.

Watanabe E, Aono S, Matsui F, Yamada Y, Naruse I, Oohira A (1995) Distribution of a brain-specific proteoglycan, neurocan, and the corresponding mRNA during the formation of barrels in the rat somatosensory cortex. Eur J Neurosci 7:547-554.

Wyss JM (1981) An autoradiographic study of the efferent connections of the entorhinal cortex in the rat. J Comp Neurol 199:495-512.

Yamada H, Fredette B, Shitara K, Hagihara K, Miura R, Ranscht B, Stallcup WB, Yamaguchi Y (1997) The brain chondroitin sulfate proteoglycan brevican associates with astrocytes ensheathing cerebellar glomeruli and inhibits neurite outgrowth from granule neurons. J Neurosci 17:7784-7795.

Yamaguchi Y (1996) Brevican: a major proteoglycan in adult brain. Perspect Dev Neurobiol 3:307-317. 